\title{
Editorial
}

CARDIOLOGY

\section{The H.J.C. Swan Memorial Prize for Medical Writing}

Five years ago, Joe Alpert, then Editor-in-Chief of Cardiology, created a Young Clinical Investigator Review Article Contest to be supported by Karger Publishers for trainees in cardiovascular diseases. Entrants needed to be no more than two years beyond their cardiology fellowship training, and could select any area of interest as the topic for review. This year, the journal has chosen to name the contest, with permission, in memory of the late H.J.C. Swan, who, in addition to his own outstanding research contributions and other publications, was a strong proponent of involvement of young cardiologists in research and medical writing. However, the rules have remained the same, as has the first prize: USD 1,000, a one-year subscription to Cardiology, and an invitation for publication of the winning article in the journal. In addition, all entrants who are selected as finalists by the panel of judges (still overseen by Joe Alpert) from the Clinical Cardiology Council of the American Heart Association, receive a year's subscription to Cardiology, and particu- larly meritorious submissions that do not win the first prize may also be published.

This year, eight finalists were selected, and three articles will be published over the course of several months. The first of these, by Srijita Sen-Chowdhry, this year's winner of the H.J.C. Swan Memorial Prize for Medical Writing, is entitled, 'Sudden Cardiac Death In The Young: A Strategy for Prevention by Targeted Evaluation', and appears in this issue. Karger Publishers and the Editors of Cardiology warmly congratulate Dr. Sen-Chowdhry for her outstanding effort, and congratulate as well the other finalists, some of whom will be recognized in these pages during the next several months. We hope that this form of recognition will be helpful in supporting development of productive careers as clinician-scientists for these young investigators.

Jeffrey S. Borer, MD Editor-in-Chief, Cardiology

\section{KARGER}

Fax +41613061234 E-Mail karger@karger.ch www.karger.com
(C) 2006 S. Karger AG, Basel

0008-6312/06/1054-0195\$23.50/0

Accessible online at:

www.karger.com/crd 